\title{
Beyond Motor Noise: Considering Other Causes of Impaired Reinforcement Learning in Cerebellar Patients
}

\author{
(D) Pierre Vassiliadis, (1)Gerard Derosiere, and (1)Julie Duque
}

https://doi.org/10.1523/ENEURO.0458-18.2019

Institute of Neuroscience, Université Catholique de Louvain, Brussels, Belgium 1200

Key words: basal ganglia; cerebellum; motor learning; motor noise; reinforcement learning

\section{Significance Statement}

Motor and reinforcement learning have been classically linked to functionally independent brain networks centered on the cerebellum and the basal ganglia, respectively. In a recent study published in eNeuro, Therrien et al. (2018) showed that increasing motor noise in healthy subjects disrupts reinforcement learning. However, this impairment remained well below that detected in cerebellar patients even when motor noise in healthy subjects was adjusted to match that observed in the patients. This suggests that impaired reinforcement learning following cerebellar damage cannot be solely accounted for by altered motor noise in these patients. Based on recent anatomic and functional evidence, we argue that the cerebellum may directly contribute to reinforcement learning, consistent with its tight connections with the basal ganglia.

The ability to adapt to changes occurring in the environment is a fundamental feature of human behavior, which relies on both sensory and reward feedbacks. On the one hand, the role of sensory feedback has been largely considered by studying how motor commands adapt to visual perturbations (e.g., a visuomotor rotation), a process called error-based learning (Shadmehr et al.,

Received November 30, 2018; accepted January 9, 2019; First published February 13, 2019.

The authors declare no competing financial interests.

Author contributions: P.V., G.D., and J.D. wrote the paper.

P.V. was a PhD student supported by the Fonds Spéciaux de Recherche (FSR) of the Université Catholique de Louvain. G.D. was a post-doctoral fellow supported by the Belgian National Funds for Scientific Research (FNRS). J.D. was supported by grants from the FSR of the Université Catholique de Louvain, and the Belgian FNRS (MIS F.4512.14).

Commentary on "Increasing Motor Noise Impairs Reinforcement Learning in Healthy Individuals" by Therrien, Wolpert, and Bastian. eNeuro. 2018 Aug 13; 5(3).

Correspondence should be addressed to Pierre Vassiliadis at pierre.vassiliadis@uclouvain.be.

https://doi.org/10.1523/ENEURO.0458-18.2019

Copyright $\odot 2019$ Vassiliadis et al.

This is an open-access article distributed under the terms of the Creative Commons Attribution 4.0 International license, which permits unrestricted use, distribution and reproduction in any medium provided that the original work is properly attributed.
2010; Wolpert et al., 2011; Kim et al., 2018; Roemmich and Bastian, 2018). This type of motor learning involves the computation of sensory prediction errors (SPEs), namely, the difference between predicted and actual sensory outcome (Tseng et al., 2007; Schlerf and Ivry, 2012; Shadmehr, 2017, 2018). On the other hand, the role of reward feedback has been mostly investigated in tasks that require learning what action to select or not, by updating reward predictions based on previous experience, a process named reinforcement learning (Lee et al., 2012; Derosiere et al., 2017a,b; Gershman and Daw, 2017; O'Doherty et al., 2017). A central aspect here is the computation of reward prediction errors (RPEs), namely, the difference between predicted and actual rewards (Schultz, 2015).

For a long time, motor learning and reinforcement learning have been studied apart and have been linked to functionally independent brain networks (Doya, 2000), mostly centered on either the cerebellum (Tseng et al., 2007; Schlerf and Ivry, 2012; Taylor and Ivry, 2014; Herzfeld et al., 2018) or on dopaminergic-basal ganglia circuits (Lee et al., 2012; O'Doherty et al., 2017), respectively. However, this view has changed in the past few years, with recent works indicating that rewards can strongly impact motor learning (Abe et al., 
2011; Izawa and Shadmehr, 2011; Dayan et al., 2014; Galea et al., 2015; Nikooyan et al., 2015; Quattrocchi et al., 2017; Song and Smiley-Oyen, 2017). Hence, efforts are now made to understand how motor and reinforcement learning may interact at the neural level (Wilkinson et al., 2015; Mawase et al., 2017; Uehara et al., 2017). Consistently, Therrien et al. (2016) recently reported data pointing toward an implication of the cerebellum in reinforcement-based motor learning. As such, cerebellar patients exhibited a reduced ability to learn from reinforcement in a visuomotor adaptation task, compared to healthy subjects (Therrien et al., 2016). However, because the patients also exhibited increased motor noise (i.e., defined as an uncontrollable source of motor variability), this deficit could have occurred indirectly, due to an impaired ability to precisely relate an action to the received reward. The work reported by the same authors in eNeuro aimed at tackling this issue by increasing motor noise artificially in healthy individuals (Therrien et al., 2018).

Therrien et al. (2018) used the same visuomotor adaptation task as in their previous 2016 paper. Specifically, the healthy subjects were required to make reaching movements toward a visual target with no visual information on the position of their hand and received binary reward feedback. To get a reward, subjects had to learn to alter their reach angle to counteract a visuomotor rotation between the location of the visual target and their hand position: the reward feedback was based on this modified reach angle. Critically, the authors added motor noise by deviating the subjects' reach in a way that was proportional to baseline motor variability. The experimental design involved both a low and a high noise condition, with the latter set to approximate the level of motor noise observed in cerebellar patients (Therrien et al., 2016). Hence, such approach allowed comparing reinforcement learning abilities between patients and healthy controls with comparable motor noise. The authors report an impaired reinforcement learning in healthy individuals in the high-noise compared to the control condition (i.e., when no noise was added). Yet, one critical result is that this impairment remained well below that observed in cerebellar patients. This finding indicates that motor noise does not entirely account for the reinforcement learning deficits observed following cerebellar damage.

A main line of argumentation in the paper focuses on the reduced proprioceptive acuity of cerebellar patients. As such, even with added motor noise, healthy subjects can still relate the rewards they receive to their reach angle, based on proprioception, while this ability is known to be altered in cerebellar patients (Miall and King, 2008; Bhanpuri et al., 2013; Weeks et al., 2017a,b). Hence, the reduction in proprioceptive precision might have indirectly altered reinforcement learning in the patients. Note though that the clinical tests run by Therrien et al. (2016) failed to reveal any reduction in proprioceptive precision in the patients. Hence, even if a discrete reduction in proprioceptive precision could have gone unnoticed based on clinical tests (Rinderknecht et al., 2018), we would like to propose that alterations in proprioceptive precision may not completely explain reinforcement learning deficits observed in the patients. Rather, cerebellar damage may directly alter reinforcement learning, as already suggested by others (Swain et al., 2011; McDougle et al., 2016; Miall and Galea, 2016).

Our viewpoint is supported by recent anatomic studies showing bidirectional connections between the cerebellum and dopaminergic-basal ganglia routes (Bostan et al., 2010; Chen et al., 2014; Bostan and Strick, 2018). Specifically, the dentate nucleus of the cerebellum sends disynaptic projections to the striatum (Hoshi et al., 2005), and to midbrain dopaminergic structures (Watabe-Uchida et al., 2012). Conversely, the cerebellar cortex receives disynaptic projections from the subthalamic nucleus (Bostan et al., 2010). Functionally, recent works in rodents provide evidence that reward expectation modulates the firing rate of cerebellar cells (Ohmae and Medina, 2015; Wagner et al., 2017; Heffley et al., 2018). In the same vein, neuroimaging studies in humans have reported activity related to RPEs in the cerebellum (O'Doherty, 2004; Ramnani et al., 2004; Seymour et al., 2004; Tanaka et al., 2004; Tobler et al., 2006; Garrison et al., 2013), suggesting that this structure is functionally involved in processing reward feedback. These works are in agreement with the result of a previous study showing that cerebellar patients exhibit altered reinforcement learning in a decision-making task requiring very simple movements (Thoma et al., 2008). In line with these considerations, structural and functional alterations of the cerebellum were found in individuals suffering from an addiction, such as alcohol or cocaine dependence, a condition characterized by abnormal reward processing (Moulton et al., 2014; Miquel et al., 2016; Moreno-Rius and Miquel, 2017). Furthermore, an important feature of reinforcement-based compared to errorbased adaptation is that the former increases trial-to-trial movement variability, reflecting an exploration process of the environment (Izawa and Shadmehr, 2011; Taylor and Ivry, 2014; Dhawale and Smith, 2017). Following this idea, modeling work in the present study showed that healthy subjects increased motor exploration following unrewarded compared to rewarded trials. This effect was absent in the patients reflecting an inability to modulate behavior optimally according to reward feedback. In this view, a recent study showed that poor performance in a visuomotor adaptation task in cerebellar patients is not only due to impaired error-based learning but also to a difficulty in using feedback information to develop and maintain an explicit aiming strategy (Butcher et al., 2017). Hence, it seems that cerebellar dysfunction could have impaired the ability to learn both from error and reward feedbacks.

Nevertheless, an important point that needs to be raised here is the age difference between the healthy subjects tested in the commented paper (Therrien et al., 2018) and the cerebellar patients to which they are compared but that were originally tested in Therrien et al. (2016). As such, the healthy subjects $(25.0 \pm 4.8$ years old) were much younger than the patients $(61.5 \pm 10.0$ years old), and in fact, when the groups were matched for age in Therrien et al. (2016), the healthy (older) controls also exhibited impaired motor exploration, to a comparable extent as the patients. This suggests that aging could 
also have contributed to the reduced reinforcement learning abilities of the patients (Chowdhury et al., 2013). Further studies are therefore required to examine the respective contribution of aging and cerebellar dysfunction to reinforcement learning.

In conclusion, the work by Therrien and colleagues provides new insights into the influence of motor noise on reinforcement learning in healthy subjects and in patients suffering from cerebellar impairment. Moreover, the data are also consistent with the view that the cerebellum may be directly involved in reinforcement learning and more precisely in reinforcement-based motor learning. Future studies could directly test this hypothesis by relating the reinforcement learning impairment of patients to their score at the International Cooperative Ataxia Rating Scale, reflecting the severity of the cerebellar impairment. This line of research opens very interesting perspectives to design innovative multi-approach neurorehabilitation strategies.

\section{References}

Abe M, Schambra H, Wassermann EM, Luckenbaugh D, Schweighofer N, Cohen LG (2011) Reward improves long-term retention of a motor memory through induction of offline memory gains. Curr Biol 21:557-562. CrossRef Medline

Bhanpuri NH, Okamura AM, Bastian AJ (2013) Predictive modeling by the cerebellum improves proprioception. J Neurosci 33:1430114306. CrossRef Medline

Bostan AC, Dum RP, Strick PL (2010) The basal ganglia communicate with the cerebellum. Proc Natl Acad Sci USA 107:8452-8456. CrossRef Medline

Bostan AC, Strick PL (2018) The basal ganglia and the cerebellum: nodes in an integrated network. Nat Rev Neurosci 19:338-350. CrossRef Medline

Butcher PA, Ivry RB, Kuo S, Rydz D, Krakauer JW, Taylor JA (2017) The cerebellum does more than sensory prediction error-based learning in sensorimotor adaptation tasks. J Neurophysiol 118: 1622-1636. CrossRef Medline

Chen CH, Fremont R, Arteaga-Bracho EE, Khodakhah K (2014) Short latency cerebellar modulation of the basal ganglia. Nat Neurosci 17:1767-1775. CrossRef Medline

Chowdhury R, Guitart-Masip M, Lambert C, Dayan P, Huys Q, Düzel E, Dolan RJ (2013) Dopamine restores reward prediction errors in old age. Nat Neurosci 16:648-653. CrossRef Medline

Dayan E, Averbeck BB, Richmond BJ, Cohen LG (2014) Stochastic reinforcement benefits skill acquisition. Learn Mem 21:140-142. CrossRef Medline

Derosiere G, Vassiliadis P, Demaret S, Zénon A, Duque J (2017a) Learning stage-dependent effect of $\mathrm{M} 1$ disruption on value-based motor decisions. Neuroimage 162:173-185. CrossRef

Derosiere G, Zénon A, Alamia A, Duque J (2017b) Primary motor cortex contributes to the implementation of implicit value-based rules during motor decisions. Neuroimage 146:1115-1127. CrossRef Medline

Dhawale AK, Smith MA (2017) The role of variability in motor learning. Annu Rev Neurosci 40:479-498. CrossRef Medline

Doya K (2000) Complementary roles of basal ganglia and cerebellum in learning and motor control. Curr Opin Neurobiol 10:732-739. CrossRef Medline

Galea JM, Mallia E, Rothwell J, Diedrichsen J (2015) The dissociable effects of punishment and reward on motor learning. Nat Neurosci 18:597-602. CrossRef Medline

Garrison J, Erdeniz B, Done J (2013) Prediction error in reinforcement learning: a meta-analysis of neuroimaging studies. Neurosci Biobehav Rev 37:1297-1310. CrossRef Medline
Gershman SJ, Daw ND (2017) Reinforcement learning and episodic memory in humans and animals: an integrative framework. Annu Rev Psychol 68:101-128. CrossRef Medline

Heffley W, Song EY, Xu Z, Taylor BN, Hughes MA, McKinney A, Joshua M, Hull C (2018) Coordinated cerebellar climbing fiber activity signals learned sensorimotor predictions. Nat Neurosci 21:1431-1441. CrossRef Medline

Herzfeld DJ, Kojima Y, Soetedjo R, Shadmehr R (2018) Encoding of error and learning to correct that error by the Purkinje cells of the cerebellum. Nat Neurosci 21:736-743. CrossRef Medline

Hoshi E, Tremblay L, Féger J, Carras PL, Strick PL (2005) The cerebellum communicates with the basal ganglia. Nat Neurosci 8:1491-1493. CrossRef Medline

Izawa J, Shadmehr R (2011) Learning from sensory and reward prediction errors during motor adaptation. PLoS Comput Biol 7:e1002012. CrossRef Medline

Kim HE, Morehead JR, Parvin DE, Moazzezi R, Ivry RB (2018) Invariant errors reveal limitations in motor correction rather than constraints on error sensitivity. Commun Biol 1:19. CrossRef Medline

Lee D, Seo H, Jung M (2012) Neural basis of reinforcement learning and decision making. Annu Rev Neurosci 35:287-308. CrossRef Medline

Mawase F, Uehara S, Bastian AJ, Celnik P (2017) Motor learning enhances use-dependent plasticity. J Neurosci 37:2673-2685. CrossRef Medline

McDougle SD, Boggess MJ, Crossley MJ, Parvin D, Ivry RB, Taylor JA (2016) Credit assignment in movement-dependent reinforcement learning. Proc Natl Acad Sci USA 113:6797-6802. CrossRef Medline

Miall RC, Galea J (2016) Cerebellar damage limits reinforcement learning. Brain 139:4-7. CrossRef Medline

Miall RC, King D (2008) State estimation in the cerebellum. Cerebellum 7:572-576. CrossRef Medline

Miquel M, Vazquez-Sanroman D, Carbo-Gas M, Gil-Miravet I, Sanchis-Segura C, Carulli D, Manzo J, Coria-Avila GA (2016) Have we been ignoring the elephant in the room? Seven arguments for considering the cerebellum as part of addiction circuitry. Neurosci Biobehav Rev 60:1-11. CrossRef Medline

Moreno-Rius J, Miquel M (2017) The cerebellum in drug craving. Drug Alcohol Depend 173:151-158. CrossRef Medline

Moulton EA, Elman I, Becerra LR, Goldstein RZ, Borsook D (2014) The cerebellum and addiction: insights gained from neuroimaging research. Addict Biol 19:317-331. CrossRef Medline

Nikooyan AA, Ahmed AA, Nikooyan AA, Ahmed AA (2015) Reward feedback accelerates motor learning Reward feedback accelerates motor learning. J Neurophysiol 113:633-646. CrossRef Medline

O'Doherty JP (2004) Reward representations and reward-related learning in the human brain: insights from neuroimaging. Curr Opin Neurobiol 14:769-776. CrossRef Medline

O'Doherty JP, Cockburn J, Pauli WM (2017) Learning, reward, and decision making. Annu Rev Psychol 68:73-100. CrossRef Medline

Ohmae S, Medina JF (2015) Climbing fibers encode a temporaldifference prediction error during cerebellar learning in mice. Nat Neurosci 18:1798-1803. CrossRef Medline

Quattrocchi G, Greenwood R, Rothwell JC, Galea JM, Bestmann S (2017) Reward and punishment enhance motor adaptation in stroke. J Neurol Neurosurg Psychiatry 88:730-736. CrossRef Medline

Ramnani N, Elliott R, Athwal BS, Passingham RE (2004) Prediction error for free monetary reward in the human prefrontal cortex. Neuroimage 23:777-786. CrossRef Medline

Rinderknecht MD, Lambercy O, Raible V, Büsching I, Sehle A, Liepert J, Gassert R (2018) Reliability, validity, and clinical feasibility of a rapid and objective assessment of post-stroke deficits in hand proprioception. J Neuroeng Rehabil 15:47. CrossRef Medline

Roemmich RT, Bastian AJ (2018) Closing the loop: from motor neuroscience to neurorehabilitation. Annu Rev Neurosci 41:415429. CrossRef Medline 
Schlerf J, Ivry RB (2012) Encoding of sensory prediction errors in the human cerebellum. J Neurosci 32:4913-4922. CrossRef Medline

Schultz W (2015) Neuronal reward and decision signals: from theories to data. Physiol Rev 95:853-951. CrossRef Medline

Seymour B, O'Doherty JP, Dayan P, Koltzenburg M, Jones AK, Dolan RJ, Friston KJ, Frackowiak RS (2004) Temporal difference models describe higher-order learning in humans. Nature 429:664-667. CrossRef Medline

Shadmehr R (2017) Learning to predict and control the physics of our movements. J Neurosci 37:1663-1671. CrossRef Medline

Shadmehr R (2018) Motor learning: a cortical system for adaptive motor control. Curr Biol 28:R793-R795. CrossRef Medline

Shadmehr R, Smith MA, Krakauer JW (2010) Error correction, sensory prediction, and adaptation in motor control. Annu Rev Neurosci 33:89-108. CrossRef Medline

Song Y, Smiley-Oyen AL (2017) Probability differently modulating the effects of reward and punishment on visuomotor adaptation. Exp Brain Res 235:3605-3618. CrossRef Medline

Swain RA, Kerr AL, Thompson RF (2011) The cerebellum: a neural system for the study of reinforcement learning. Front Behav Neurosci 5:8. CrossRef Medline

Tanaka SC, Doya K, Okada G, Ueda K, Okamoto Y, Yamawaki S (2004) Prediction of immediate and future rewards differentially recruits cortico-basal ganglia loops. Nat Neurosci 7:887-893. CrossRef Medline

Taylor JA, Ivry RB (2014) Cerebellar and prefrontal cortex contributions to adaptation, strategies, and reinforcement learning. Prog Brain Res 210:217-253. CrossRef Medline

Therrien AS, Wolpert DM, Bastian AJ (2016) Effective reinforcement learning following cerebellar damage requires a balance between exploration and motor noise. Brain 139:101-114. CrossRef Medline

Therrien AS, Wolpert DM, Bastian AJ (2018) Increasing motor noise impairs reinforcement learning in healthy individuals. eNeuro 5: ENEURO.0050-18.2018. CrossRef Medline
Thoma P, Bellebaum C, Koch B, Schwarz M, Daum I (2008) The cerebellum is involved in reward-based reversal learning. Cerebellum 7:433-443. CrossRef Medline

Tobler PN, Doherty JPO, Dolan RJ, Schultz W, Philippe N, Doherty JPO, Dolan RJ (2006) Human neural learning depends on reward prediction errors in the blocking paradigm. J Neurophysiol 95:301310. CrossRef Medline

Tseng Y, Krakauer JW, Shadmehr R, Bastian AJ (2007) Sensory prediction errors drive cerebellum-dependent adaptation of reaching. J Neurophysiol 98:54-62. CrossRef Medline

Uehara S, Mawase F, Celnik P (2017) Learning similar actions by reinforcement or sensory-prediction errors rely on distinct physiological mechanisms. Cereb Cortex 28:3478-3490. CrossRef Medline

Wagner MJ, Kim TH, Savall J, Schnitzer MJ, Luo L (2017) Cerebellar granule cells encode the expectation of reward. Nature 544:96100. CrossRef Medline

Watabe-Uchida M, Zhu L, Ogawa SK, Vamanrao A, Uchida N (2012) Whole-brain mapping of direct inputs to midbrain dopamine neurons. Neuron 74:858-873. CrossRef Medline

Weeks HM, Therrien AS, Bastian AJ (2017a) Proprioceptive localization deficits in people with cerebellar damage. Cerebellum 16:427437. CrossRef Medline

Weeks HM, Therrien AS, Bastian AJ (2017b) The cerebellum contributes to proprioception during motion. J Neurophysiol 118:693702. CrossRef Medline

Wilkinson L, Steel A, Mooshagian E, Zimmermann T, Keisler A, Lewis JD, Wassermann EM (2015) Online feedback enhances early consolidation of motor sequence learning and reverses recall deficit from transcranial stimulation of motor cortex. Cortex 71:134-147. CrossRef Medline

Wolpert DM, Diedrichsen J, Flanagan JR (2011) Principles of sensorimotor learning. Nat Rev Neurosci 12:739-751. CrossRef Medline 